\title{
2
}

\section{Religious discourse concerning blasphemy: Politics of uncertainty and legitimacy}

\author{
Batla do gustaakh-e-nabi ko, ghairat-e-Sunni zindaa hai \\ Deen pe mar mitnay ka jazba, kal bhi tha aur aaj bhi hai! \\ [Tell the blasphemer of the Prophet, the honour of Sunnis is alive \\ We always had the passion to die for our religion, and still have it!] \\ Jaag uthay hain ahl-e-sunnat, goonj utha ye naara hai \\ Door hatto aye dushman-e-millat, Pakistan humara hai! \\ [Ahl-e-Sunnat (Sunnis) have awakened, and their slogan is echoing: \\ Get out of the way, $\mathrm{O}$ enemy of the nation! Pakistan belongs to us.] \\ Sunnio, apnay aap ko ghair syasi kehna chor do, \\ Ab baat namoos-e-risaalat ki hai \\ [O Sunnis, stop calling yourselves apolitical, \\ It is about the Prophet's honour now!]
}

These are some of the slogans that have been popular among various Sunni groups, particularly the Barelwis, over the past decade or so. Arising as a reformist movement in colonial India, the Barelwis-the largest section of Sunni Muslims in Pakistan-have always played a political role in Pakistan's history through street protests, lobbying and political coalitions (Khan 2011: 61; Philippon 2014). However, they have become increasingly politicised since the 2000s, actively defending 'their religious identity and heritage' (Epping 2013: 1). Barelwis have been popular targets for sectarian violence-such as bombing of their shrines and religious celebrations - at the hands of Deobandis, another Sunni reformist group (Khan 2011: 64). Barelwis' increased political activism is 
therefore often understood as a response to Deobandi militancy against them (Epping 2013; Khan 2011). It has also been argued that the rise of Barelwi activism is a direct result of the post-9/11 institutionalisation of Barelwi Islam by Pakistan's government in an attempt to combat Deobandi terrorist outfits, whom the government and the military had previously sponsored (Suleman 2018). Nevertheless, today, Barelwis are at the frontline of campaigns to defend the honour of the Prophet and punish all blasphemers.

While scholars of almost all sects, schools of thought and religious groups in contemporary Pakistan ${ }^{1}$ support the mandatory death sentence for a blasphemer, the Sunni Barelwi groups have, in particular, established the issue of blasphemy as the pivotal point of their political claims in the recent past (Basit 2020). They have positively aligned the ideology of Pakistan with the aim of defending the honour of the Prophet, as indicated by the following slogan:

Pakistan ka matlab kya? La illaha illallah

Dastoor-e-reyasat kya hoga? Muhammad ur Rasool Allah

[What does Pakistan mean? There is no God but Allah.

What shall the principle of our state be? Muhammad is the

Prophet of Allah.]

The first line is popularly known as the political slogan of the Pakistan Movement in the pre-Partition campaign for a separate homeland for Muslims (Butt 2016: 11). ${ }^{2}$ The second line is an extension recently added by the Sunni Barelwi groups engaged in anti-blasphemy campaigns. It is a claim as to what 'the idea of Pakistan' means and how it should be implemented by the state. As discussed in the previous chapter, the process of state formation in Pakistan has always been characterised by competing ideas of nationhood. In this chapter, I will demonstrate how certain groups are (re)imagining and campaigning to promote their ideas of the state in Pakistan, participating in the ongoing 'battle of imagination'

1 There have been some attempts to challenge the dominant interpretations about the punishment of blasphemy from within the religious traditions, but they remain minority voices without much support. One religious scholar, Javed Ahmed Ghamidi, questioned the existing law and argued that it was not in accordance with the Quran, but he had to flee Pakistan in fear of his life. Currently, Arafat Mazhar, a young scholar, is involved in challenging the religious scholars and inviting them to debate the theological basis of the punishment of a blasphemer (Alvi 2015; Mazhar 2018).

2 However, researchers have shown that this slogan was not supported by the leadership of the Pakistan Movement, and that it was under Zia-ul-Haq's regime that this slogan was written into history as the slogan of the Pakistan movement (Paracha 2013; Wasti 2009: 4-5). 
(Appadurai 1990: 303-4). Love of the Prophet Muhammad and defence of his honour have come to be central to contemporary ideas about nationhood among the dominant religious groups.

I argue that mainstream religious leaders and scholars have popularised an absolutist discourse about blasphemy and its punishment to gain political legitimacy and religious authority for themselves, in the process granting certain symbolic meaning and significance to the issue of blasphemy. This symbolic meaning is then harnessed by more individuals and groups to gain influence, legitimacy and power in the religious and political domains. The symbolic power of blasphemy works by generating certain affective responses from believers, through their bodily and sensory experiences as well as their devotion to the cause. Thus, I contend that the popular religious discourse around blasphemy should be understood within the context of a power struggle between religious scholars, the meaning it holds for believers and the affective responses it generates.

\section{Affect, meaning and power: An integrative approach}

There is only one punishment for the blasphemer of the Prophet

Beheading, beheading!

O blasphemer of Muhammad! You are not safe anymore

We will lay down our hearts and our bodies for the sake of the honour of the Prophet

[We] Muslims will behead all the blasphemers!

This is the chorus from a na'at ('song') praising the Prophet often played at anti-blasphemy gatherings and protests. The first two lines are also used as a slogan, chanted, printed and sung by anti-blasphemy campaignersparticularly Sunni Barelwis. The original video for the song, sung by Aftab Qadri, shows a young bearded man in embroidered attire and a glittery turban standing in front of trees lit by fairy lights, singing the above lines to a very catchy tune. ${ }^{3}$ The singer begins with an extremely passionate recitation to warn blasphemers of the power of Muslims' faith and love for the Prophet. The vocals and the music invoke certain visceral responses by creating a sense of urgency and instilling a sense of empowerment. While listening to this na'at, I experienced an increased heart rate and felt

3 The video can be found on YouTube: www.youtube.com/watch?v=jyPmYFVefr8. 
a surge of energy course through my body. After listening to it a few times, I was also subconsciously humming the chorus. No wonder it is a popular slogan and is used in religious gatherings to generate affective responses from the crowd.

Affective responses are understood by psychologist Silvan Tomkins (2009: $163)$ as the 'primary innate biological motivating mechanism'. Affects are thus understood as non-linguistic and non-ideological aspects of human behaviour related to the senses and bodily processes that are not entirely located in consciousness. My heart rate increasing while listening to this na'at was thus an affect-my body's natural reaction to the aural experience-even though the words being uttered had no meaning for me. Brian Massumi (2002:30-35), a leading affect theorist, distinguished between affects and emotions, arguing that affects are purely subconscious and autonomous whereas emotions are imbued with meaning. He argues that affects have an intensity of their own that can produce certain effects and motivations in individuals and groups of people (Massumi 2002).

Such an understanding of affect has been criticised as anti-intentionalist, giving an autonomous and pre-personal existence to 'affect' as a 'natural' element of the human body, rather than constructed within social conditions (Leys 2011: 470). Leys argues that affect theory discerns affects as 'inhuman', 'pre-subjective', 'visceral' forces and 'intensities that influence our thinking and judgments but are separate from these' (2011: 437). In her view, affect theorists put an almost excessive emphasis on bodily and corporeal processes stripped of meaning and social conditions, to counter post-structuralist theory's obsession with meaning, ideology and discourse (Leys 2011: 440-41). The resulting theory then sees:

the subject's affects and its cognition or appraisal of the affective situation or object, such that cognition or thinking comes 'too late' for reasons, beliefs, intentions, and meanings to play the role in action and behaviour usually accorded to them. The result is that action and behaviour are held to be determined by affective dispositions that are independent of consciousness and the mind's control. (Leys 2011: 444)

The disconnect between ideology and affect thus underplays the role of ideas and beliefs in people's behaviour and motivations (Leys 2011: 451). Even though the na'at about beheading blasphemers evoked a physical response in me, it did not produce any motivation because I do not subscribe to the ideas being presented. Therefore, I agree with Leys's 
criticism of affects as the 'primary innate biological motivating mechanism' devoid of meaning. Physical responses certainly have a role to play in individual and collective life; for example, participants at anti-blasphemy protests respond with a certain fervour to Arabic and Persian recitationslanguages most of them do not understand but associate with religious value. The sensory experience of hearing recitations, music and poetry at religious gatherings does indeed produce certain affective responses. However, the biological responses alone cannot produce motivations and judgements.

The symbolic meaning associated with Arabic and Persian recitations is what turns the biological responses into devotion. While I can be drawn into subconsciously humming the chorus of a song, I do not automatically feel motivated to act on it. Nor does the sound of the chorus autonomously produce any devotion in me. For the people participating in anti-blasphemy protests, on the other hand, the same chorus not only produces devotion and motivation, but may also lead them to act and kill alleged blasphemers. They are already committed to an ideology or set of ideas — seen as secondary by affect theorists — that generate passionate reactions. Thus, I see affect as crucial to understanding the dominant discourse on blasphemy, but only in conjunction with the meaning transmitted through this discourse. Affect, in my understanding, adds intensity to meaning instead of meaning adding purpose to intensity. That is, the affect-or intensity—is not prior to the meaning. The intensity generated by the affect, however, turns ideas into passions and meaning into embodied devotion.

Geertz (1993: 90) emphasised the significance of symbolic meaning in producing religious 'moods and motivations'. He understood religion as a system of interconnected symbols that give meaning to religious experience. He defined religion as:

(1) a system of symbols which acts to (2) establish powerful, pervasive, and long-lasting moods and motivations in men by

(3) formulating conceptions of a general order of existence and

(4) clothing these conceptions with such an aura of factuality that

(5) the moods and motivations seem uniquely realistic. (Geertz 1993: 90) 
I follow the Geertzian concept of symbolic meaning to understand how religious discourse creates certain moods and motivations in the supporters of anti-blasphemy violence. Thus, I analyse the popular religious discourse concerning blasphemy with attention to the affect and the meaning it engenders among believers.

While Geertz (1993: 125) acknowledged that religion as a system of symbols is also related to 'socio-structural and psychological processes' and is culturally specific (p. 123), Asad (1983) criticised him for ignoring the role of power in determining historically specific understandings and experiences of religion. Emphasising the role of historical power relations and processes, Asad argues that we should pay attention to:

the conditions (discursive and non-discursive) which help to explain how symbols come to be constructed, and how some of them are established as natural or authoritative as opposed to others. (Asad 1983: 240)

I agree with Asad's emphasis on the role of power in the construction of meaning. I focus on the discursive construction of the symbolic meaning of blasphemy-following a long tradition of Foucauldian discourse analysis. For Foucault (1971: 8), discourse means whatever determines the way in which at a given point in history one can think, speak or write about a social object or practice. Discourse is historically specific and grounded in the sociopolitical context, which implies that, in a given context, reality or truth is the function of what can be thought, written or said at a given point in time (Foucault 1971: 15). The historical circumstances are the conditions of possibility that constrain discursive formations. Therefore, social imagination is determined by a particular set of material conditions and their representations at any given point in history (Foucault 2002: 145). Following this conception, I understand the symbolic meaning of blasphemy as being constructed discursively within the context of power relations.

However, I also argue that the symbols thus constructed may attain power of their own and can empower more people in their course. Therefore, as Geertz pointed out in an interview in response to Asad's critique, the religious symbols cannot be reduced to power relations (Micheelsen 2002: 8-9). While power relations determine which symbols become important and what meaning they hold, the symbols also provide meaning for those concerned and at the same time generate for them certain affects. While the religious discourse concerning blasphemy in present-day Pakistan 
has obvious political undertones and is a product of specific historical and political circumstances, it also provides affective meaning to those involved in the discourse, whether they are religious scholars or ordinary people. Thus, I contend, power relations and (affective) meaning cannot be entirely separated from each other; rather, they share a dialectic relationship in which power creates (affective) meaning and meaning can grant power in turn.

The discussion of the dominant religious discourse in the first section of this chapter is mostly concerned with the affective meaning this discourse holds for believers. In the second section, through a discussion of the role of religious authority and political motivations that determine the religious discourse about blasphemy, I will demonstrate, in line with Asad's argument, that historically specific power relations determine religious symbols, as well as the moods and motivations they produce in people.

\section{The dominant religious discourse concerning blasphemy}

Despite a general consensus among religious groups on the punishment for an alleged blasphemer, there is a proliferation of literature and speeches on the issue of blasphemy. I studied more than 50 book-length publications from Islamic scholars of all major sects and religious groups on the topic of blasphemy. These included (semi-)fictional stories as well as nonfiction interpretational texts. The (semi-)fictional stories-such as the novelette Shaatam (Blasphemer) by Mukhtar Alam-revolve around stories of blasphemers. These stories almost always start from their birth as 'illegitimate' children. The storylines lead up to the offence of blasphemy, or tauheen-e-risaalat ('insult of the Prophet'), committed by them and their ibrat-naak anjaam ('horrifying destiny') at the hands of the 'heroes', or aashiqan-e-rasool ('lovers of the Prophet'), who kill them. These stories are imbued with passion and are a source of affective meaning for their devoted readers.

A pattern can also be drawn out of the interpretational texts in terms of the structure and content of these publications. Most publications include some form of the following components: the centrality of love for the Prophet Muhammad to Muslims' faith; examples of love for the Prophet from his companions and later Muslims; the absolute authority of the 
Prophet; Quranic and prophetic traditions regarding punishment for those who insult or question the Prophet; what actions, words, gestures and attitudes constitute insult to the Prophet; examples of 'blasphemers' who met their destined 'horrific' deaths at the hands of Muslims; characteristics of blasphemers; and blasphemy as a conspiracy of the West, non-Muslims, Jews or anti-Islam forces to undermine Islam. These texts are written in passionate language and are sources of emotional as well as ideological meaning for readers.

In addition to the Quranic references and prophetic traditions, many of these publications include verses from the modernist South Asian philosopher-poet Allama Muhammad Iqbal, who is commonly known as a passionate lover of the Prophet and the visionary of Pakistan. Specifically, his verses dealing with love of the Prophet and the call for Muslims to be active against the enemy-the colonial forces at the time he was writing - are often cited. Not surprisingly, the same topics and references were popular in religious sermons and speeches made at protests and were highlighted by religious scholars during my interviews with them. Based on such religious publications, sermons, speeches and my interviews with religious scholars, I will discuss some of the key themes mentioned above that make up the prevailing discourse on blasphemy and its punishment in Pakistan. I will begin with the discourse of contemporary scholars from three religious groups and then discuss the religious sources or Islamic juristic literature to which they refer.

The religious scholars to whom I refer are also active politicians. In fact, most of the religious groups and organisations actively engaged in the anti-blasphemy campaigns in Pakistan are also political parties. Some of them have been in existence since the conception of Pakistan and have played an active role in achieving Pakistan's anti-blasphemy laws as they exist today; others have entered the political scene much more recently, specifically rallying around the issue of blasphemy. I will focus on three religious political parties-formed at different stages in the history of Pakistan - that are currently engaged in the anti-blasphemy discourse around the country. Jamaat-e-Islami (JI) Pakistan was formed in 1941, Pakistan Awami Tehreek (PAT) was formed in 1989 and Tehreek-eLabbaik Pakistan (TLP) was formed in 2015. All three of these parties belong to the Sunni sect, with PAT and TLP representing the Barelwi subsect of Sunni Islam. 


\title{
Love for the Prophet Muhammad
}

\author{
Ki Muhammad se wafa'a tu ne tou hum teray hain \\ Ye jahan cheez hai kya, Loh-o-qalam teray hain \\ [Be loyal to Muhammad, and you will have me on your side; \\ The world is nothing, you will command My Pen of Destiny.] \\ - Allama Muhammad Iqbal, 1913
}

The above verse appears in Iqbal's poem 'Jawab-e-Shikwa' ('God's Answer to Muslims' Complaint'), which was a sequel to his poem 'Shikwa' ('The Complaint'). Together, these poems are in the format of a dialogue with God. In the first poem, Iqbal complains about the miserable situation of Muslims on the Subcontinent and beyond despite them being the followers of the rightful religion. In the second part, God responds to highlight the shortcomings of Muslims that are responsible for their abject condition in the world and offers ways to rectify that. The verse quoted above is the closing couplet of the second poem. Thus, loyalty to Muhammad is argued to be the answer to all of Muslims' problems in the contemporary world. This couplet is one of the most popular references to Iqbal's poetry made by the anti-blasphemy campaigners in present-day Pakistan. The couplet engenders intense passion among believers and is quoted in books, recited in sermons and has also been sung as a na'at in praise of the Prophet. The verses are employed to argue that love of the Prophet and faithfulness to him are the most powerful tools in the hands of Muslims. Love of the Prophet is what distinguishes Muslims from the rest of the world and is the only way to achieve success and power.

The figure of Muhammad has been a popular subject of devotional literature in most Muslims societies (see, for example, Asani et al. 1995). However, while the centrality of the Prophet to Muslims' faith is common to most sects and subsects in Pakistan, the Barelwis have been known for their exceptional devotion and passionate attachment to the personality of Muhammad. For Barelwis, 'a true Muslim is an "Ashiq-e-Rasool", or a "Lover of the Prophet", who is 'obligated to protect the sanctity of the Prophet' (Khan 2011: 60). The Prophet is the spiritual axis of faith as well as the perfect role model for living in this world. Even mentioning the name of the Prophet invokes affective and emotional responses-such as a lowering of the gaze- because of the meaning attached to his personality. However, this is precisely the concern for which different Barelwi groups compete among each other-and against other Sunni subsects-in 
the shared religious-political sphere. The following discussion deals specifically with the popular ideas of love of the Prophet among Sunni Barelwi groups in Pakistan.

One of the senior lecturers at Minhaj-ul-Quran, a Sunni Barelwi religious institute affiliated with PAT, who teaches postgraduate students and prided himself on having supervised many theses, told me that the starting point of my $\mathrm{PhD}$ thesis should be the different conception of the Prophet in Islam compared with that in 'the West'. He emphasised the 'relative concept of prophethood' and the 'different concepts of insult in Islam as compared with other religions' as crucial to understanding the issue of blasphemy in Pakistan. He said:

Our conception of the Prophet is very different from that of the West for whom their prophets ${ }^{4}$ are just like other human beings. For us, Prophet Muhammad is not merely a human being. He is a transcendental spiritual being, with the highest status even amongst the spiritual beings. An insult against human beings cannot be compared to insult against the highest spiritual beingour Prophet Muhammad.

According to him, insult of the Prophet is not merely hate speech (a Western concept that he mentioned); rather, it is the most serious of sins. When I asked him to elaborate, he responded:
Because our faith is based upon unconditional love for the Prophet Muhammad. It is what sets us apart from other religions. This love is the condition of our faith; one cannot be a Muslim if one does not hold the Prophet Muhammad in the highest reverence and dearer than his own life, wealth, family and children. The unconditional love demands that we do not tolerate even a little doubt on the personality of Muhammad and the religion he brought to us.

Interestingly, similar arguments about the different conceptions of the Prophet in Islam compared with those in the West, and the different understandings of insults to the Prophet in contrast with the Western notion of hate speech, have also been made by anthropologist Saba Mahmood (2009) in her work on Muslims' reactions to the Danish cartoons. She argued that there is a different 'modality of attachment' between a devout Muslim and the Prophet Muhammad, embedded in a different 'economy of signification' (Mahmood 2009: 76). In this economy of signification,

4 Referring mainly to Christianity and Judaism. 
the Prophet Muhammad is a figure of immanence in his constant exemplariness, and is therefore not a referential sign that stands apart from an essence that it denotes' (Mahmood 2009: 76). The moral injury thus experienced by insult to the Prophet:

emanates not from the judgment that 'the law' has been transgressed but from the perception that one's being, grounded as it is in a relationship of dependency with the Prophet, has been shaken. (Mahmood 2009: 78)

Hence, she argued that the moral outrage of Muslims in response to the insult of the Prophet is embedded in their unique religious ethos, which is qualitatively different from that of Western societies.

However, the supposedly unique ways of attaching to the Prophet-the distinctly Muslim ethos-is very hard to define. In fact, it is one of the major points of difference between various groups and sects within Islam. Barelwis and Deobandis, for example, passionately disagree on the nature of the Prophet's existence and appropriate modes of attachment to him. The former believe the Prophet is not only a physical existence; rather, he is a part of the noor ('light') of God that existed before anything else was created and will last beyond everything in the universe; and, by virtue of this spiritual existence, the Prophet's physical death does not mark his disappearance from the world; he is all-present and always existing (Khan 2011: 59). Deobandis, on the other hand, believe that while Muhammad was a prophet of Allah, he was a human being like all other human beings, who died a physical death after fulfilling the role he was assigned to play (Khan 2011). They believe that the conception of Muhammad as anything more than a human being elevates his status to divinity and this corrupts the monotheistic spirit of Islam (Khan 2011).

While all sects agree on the authority of Muhammad and respect for him, different conceptions of the nature of the Prophet also entail distinct ways of attaching to and displaying love for him. One group's way of respecting the Prophet may be seen as an insult by the other group. Therefore, Sunni Barelwis and Deobandis, Wahabbis, Salafis and Ahl-e-Hadith accuse one another of blasphemy. Even among Barelwis, there are different conceptions of how to love the Prophet. Love for the Prophet, therefore, becomes the domain in which they actively compete against each other, to establish themselves as more authentic lovers of the Prophet than others. Thus, while they all agree on the centrality of the Prophet Muhammad to Muslims' faith, they contest what the appropriate reverence accorded to 
the Prophet must look like and, by corollary, the understandings of what is blasphemous and what is not. Here I will only discuss in detail some of the examples of 'how to love the Prophet' as promulgated by the two Barelwi groups, PAT and TLP.

Despite their beliefs concerning the spiritual aspects of Muhammad's existence, Sunni Barelwis put an almost obsessive emphasis on reverence of the physical being of Muhammad. Love of the Prophet in the present world, for them, is marked by imitating his physical features (for example, facial hair), eating what he ate, drinking what he drank and living life as closely as possible to his. There are numerous traditions of the Prophet's everyday life referred to in the everyday lives of Pakistani Muslims. The standards of love for the Prophet were set by his companions who lived in his time, according to the prevalent religious discourse among Sunni Barelwis. They quote acts of reverence accorded to the Prophet by his companions to set forth a model for believers, who are supposed to love the Prophet more than they love their own lives, families and wealth. One such example of his companions' reverence for the Prophet, narrated by Muhammad Tahir-ul-Qadri, the founder of PAT, is as follows:

The companions of the Prophet highly revered anything associated with the Prophet and everything that came in contact with his Holy body. Urwa bin Mas'ood, who converted to Islam, narrated: 'By God, he [the Prophet Muhammad] would spit and his companions would collect it on the palms of their hands and rub it on their faces.' Whenever any discharge from Prophet Muhammad's mouth or nose dripped, his companions would rush towards him to collect it on their hands and rub it on their faces and bodies. Now, we must pay attention to who was indulged in these acts: it was [the three caliphs] Hazrat Abu-Bakr Siddique, Hazrat Umar Farooq, Hazrat Ali and fifteen hundred other companions of the Prophet ... The Prophet did not stop them, neither did any revelation from Allah. How could it be stopped? This intense passionate relationship with the Prophet is the very spirit of the faith—-the truth of the faith—that was well acknowledged by the companions of the Prophet. (Tahir-ul-Qadri 2013: 49)

Other similar examples narrate how his companions would not allow the water used during the Prophet's ablution to go to waste, how they kept the Prophet's hair from falling to the ground, how their eyes looked down and their voices stayed low in the presence of the Prophet, and 
so on. Reverence of the Prophet is often talked about in terms of ghulaami (lit.: 'slavery') to the Prophet as the ideal to be achieved and a source of pride for his followers. Tahir-ul-Qadri (2013: 52) writes:

Destroying one's self in the Prophet's slavery is the only complete faith and crossing all limits in his respect and veneration is the true devotion to the Prophet, and devotion is the pinnacle of faith.

Thus, there is an emphasis on complete devotion to the Prophet-not only in thoughts, but also through the body. A lover of the Prophet submits to him cognitively, physically and affectively_all at the same time.

The late Allama Khadim Hussain Rizvi, leader of TLP, while addressing a crowd on the anniversary of the death of Amir Cheema-a young engineering student who died in 2006 in a German prison after attempting to assassinate Roger Köppel, editor of the German daily Die Welt, which published cartoons of Muhammad-gave an example of crossing the limits. He narrated the story of a woman who drank the Prophet Muhammad's urine and then went on to describe its 'delightful' taste and smell as priceless. He called it 'blind love for the Prophet Muhammad' and aroused the crowd by rhetorically asking them what they had done to show their love for the Prophet? The crowd was impassioned and chanted slogans of praise and reverence for the act of drinking the Prophet's urine. In his speech, Rizvi asserted that, in the present day, giving one's life to protect the honour of the Prophet Muhammad is the ultimate act of love, as shown by Amir Cheema, Mumtaz Qadri and many others who died while guarding the honour of the Prophet. Those present in the crowd raised their hands and registered their physical presence to reaffirm that they were willing to lay down their bodies in love for the Prophet.

The emphasis on love for the holy Prophet as a bodily practice appears to be the underlying theme of notions of love for him, especially among Sunni Barelwis. ${ }^{5}$ This understanding of love is connected to biological processes, from identifying with the body of the beloved in certain ways and revering their bodily fluids, to sacrificing one's own body for the sake of the beloved. Similar examples of embodied devotion have been cited in the wider literature on Sufi practices in South Asia (for example, Werbner and Basu 1998: 10). Parallels can be drawn with the emphasis on bodily practices with respect to the holy in South Asian religious communities

5 Similar notions are found in Shia conceptions of love for holy persons in Pakistan, as well as in some other sects. 
in general. In particular, in Hinduism, the notion of holiness is overtly manifested in the physical world. From using cow's dung to consecrate physical spaces to drinking cow's urine for purification purposes, the relationship between the ordinary (profane) and the holy (sacred) is conceived in terms of physiological and bodily processes (Korom 2000: 193-95). The centrality of notions of purity to such a conception of love for the holy is also significant. ${ }^{6}$ It is the holy that can not only transcend the normally perceived boundaries of the pure and impure, but also purify the impure. If the impure crosses the boundary, it is a transgression. However, what is normally perceived as impure-such as urine-is not only pure but also purifying when it comes from a holy body.

Muslims in Pakistan widely condemn Hindu practices such as drinking the urine of a cow, but at the same time, at least some groups glorify the act of drinking the Prophet Muhammad's urine. It can be argued that such a conception of love for the Prophet has developed within South Asian culture and draws on the same ideas of physicality, sacredness and purity as do Hindus. Barelwi Muslims, while claiming to oppose Hindu rituals, themselves subscribe to notions of purity and holiness as embedded in bodily processes. There is another significance of relating to the Prophetor any holy symbol - through bodily practice: it is visible to others and is therefore an act of public performance. It is within the public sphere that it becomes a marker of identity, embedded in the body-or the death of the body. The ways of loving the Prophet are thus embodied techniques of the self, as they enable individuals to discover meaning for their own selves and establish their purity in contrast to others. The emphasis on the body adds intensity to meaning and inculcates embodied devotion. It is through the body that love for the Prophet must be expressed, and an offence against the Prophet must also be avenged such that the body of the offender bears the punishment. It is visible to the world and a clear sign-engraved on the bodies of the avenger (the lover of the Prophet) as well as the offender (the blasphemer) — of the pious self as distinct from the other.

6 While Dumont's (1980) thesis on purity and impurity as the primary basis of India's caste system has been challenged (see, for example, Marglin 1977; Olivelle 1998), the significance of the ideas of purity and impurity to the South Asian cultures is generally acknowledged. 


\section{'Religious sources' concerning the punishment of blasphemy in popular discourse}

As mentioned earlier, religious scholars from all schools of thought in present-day Pakistan agree that whoever insults the Prophet Muhammad must be killed. Most accusations that include the act of insulting anything related to the religion of Islam, its dominant understanding and practices and even the authority of religious scholars can be framed as tauheen-erisaalat ('insult to the Prophet'). According to the Pakistan Penal Code (PPC), religious offences other than insult to the Prophet Muhammad are punishable by life imprisonment and fines rather than death. However, in the popular discourse, such distinctions are rarely made, and the death penalty is promoted for a wide range of offences. For example, in justifying the murder of Salman Taseer, who did not directly insult the Prophet Muhammad but questioned the misuse of anti-blasphemy laws against religious minorities, religious scholars described his crime as insulting the 'law of God'. They argued that it was in effect an insult to the Prophet. Consequently, the popular term used to rally against Taseer for his offence was tauheen-e-risaalat. Similarly, religious scholars have described acts as various as insulting men's beards, criticising the Pakistan Army and supporting religious minorities as tauheen-e-risaalat. Thus, almost anything can be subsumed as an insult to the Prophet, deserving death as punishment.

Religious scholars refer to various sources in the Quran and hadith literature to support their belief that anyone who insults the Prophet must be killed. Such references add authenticity to meaning for people. Tahirul-Qadri, in his book Tahhafuz-e-namoos-e-risaalat (Defending the Honour of the Prophet) refers to Quranic verse Al-Ahzab 33:61:

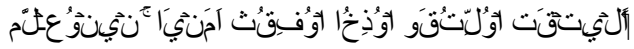

[They shall be cursed from all around and they shall be ruthlessly

killed wherever they are seized.] ${ }^{7}$

7 There are multiple translations and interpretations of the verses of the Quran, which I am not concerned with here. My aim is not to confirm or contest the authenticity of the interpretations but to highlight the prevalent discourse. 
In his interpretation of this verse, Tahir-ul-Qadri (2013: 21-22) writes:

Thus, the Almighty is saying, 'O man! Don't show any empathy or leniency towards those who insult the sacred personality of my beloved [Prophet Muhammad]. Don't allow them any sort of consideration because they have gone miles away from my mercy; rather [they] have become totally devoid of it. So, where and whenever you find them, destroy their irreverent existence. Because even my merciful nature cannot tolerate their obscenities against my beloved. I cannot bear fearless existence of their filthy bodies on my pure and sacred land.'

He further comments on the choice of words by 'the Almighty' in the abovementioned Quranic verse. He asserts that the final two words are a repetition of the Arabic word for killing, which implies that not only should blasphemers be killed, but also 'they should be killed as is the right to be killed' - that is, 'as brutally as possible' (Tahirul-Qadri 2013). Once again, through an emphasis on the physical act of killing, the meaning of punishment is intensified. Tahir-ul-Qadri (2013: 22) goes on to argue that this Quranic verse forms the basis of the 'eternal, indispensable law of God' concerning the punishment of a blasphemer and no human can make even a slight change to it. He argues that this is a hadd ('mandatorily enforced law') rather than a tazeer ('discretionary law'). He defines hadd as a punishment 'prescribed by Allah, that cannot be amended or altered by anyone except Allah' (Tahir-ul-Qadri 2013: 25). Hence, he argues, there is no room for forgiveness of a blasphemer. One of the senior scholars at JI headquarters described a similar position to me:

It is not possible to forgive the blasphemer. The biggest example is the conquest of Mecca when the Prophet forgave everyone except those who had committed blasphemy. Even if one is himself sinful, it is mandatory to punish the blasphemer. One's sins can be forgiven by Allah; not practising Islam properly is a personal matter between him and Allah. However, not believing and insulting the religion of Islam is an unpardonable sin.

A similar distinction between lesser sins (related to the practice of faith) and the ultimate sin (insulting the religion and the Prophet) is drawn by Tahir-ul-Qadri. He argues, if one practices every component of Islam faithfully but does not appropriately revere the Prophet, he remains an infidel. On the other hand, one who does not practise Islam properly, but whose heart is filled with love for the Prophet, is still a Muslim and has hope for salvation from their sins. The former is kharij-al-imaan ('outside the 
circle of Islam') while the latter is na'qas-al-imaan ('incomplete in faith') (Tahir-ul-Qadri 2013: 35). He also suggests that blasphemy is equal to infidelity and apostasy. In effect, this means that the private practice of faith is treated differently to insult or denunciation of the religion, which is carried out in the public sphere. Insulting the religion or the Prophet is treated as a public offence that is subject to regulation and punishment by the community. Hurting the religious feelings of others is therefore the ultimate offence.

However, in his commentary on 295-A, the clause of the PPC according to which anyone can be punished for insulting any other person's religion or religious feelings, Tahir-ul-Qadri also argues that the punishment for hurting the religious feelings of non-Muslims is tazeer but hurting Muslims' religious feelings is a hadd. This is because:

when it comes to the insult of Prophet Muhammad, it no more remains an issue of hurting Muslims' feelings; it becomes an issue of destabilising Islam ... and only Islam is the religion of truth in the present world whereas all other religions are either false, adulterated, or obsolete. (Tahir-ul-Qadri 2013: 29)

An insult to Islam and the Prophet of Islam is therefore a threat to the public order as perceived by Muslims. Similar arguments are made by other religious scholars. A senior scholar of JI with a doctorate in Islamic studies said in an interview with me:

There are several such cases within the lifetime of the Prophet that demonstrate that neither the Prophet nor Allah tolerated anyone who insulted the Prophet or questioned his authority. Even in the Quran, Allah says, whoever hurt my beloved Prophet will be damned in the world as well as in the hereafter. In another place in the Quran, Allah says, kill the blasphemers wherever you find them. The Prophet did not punish those who took it upon themselves to kill the blasphemers. It doesn't matter if those killers [lovers of the Prophet] practise the religion properly or not or offer their prayers or not.

There are plenty of references to other prophetic traditions with a similar message. Below are (summarised versions of) some of the most quoted prophetic traditions, across the three religious organisations on which I am focusing, which are used to support the killing of blasphemers: 
- There was a blind man, who killed his slave girl. He came to the Prophet and confessed that he had killed his son's mother. He said he killed her because she used to constantly say derogatory words about the Prophet Muhammad. He stopped her a couple of times, but she did not stop insulting the Prophet. On hearing this, the Prophet did not denounce his act. Rather, he praised it and said this murder was void - that is, there would be no repercussions for the killer.

- On the occasion of victory over Mecca, the Prophet graciously announced public forgiveness for everyone in the city. However, he did not forgive the blasphemers. He issued a list of five or six people who used to say blasphemous things about the Prophet. The Prophet ordered that they should be killed even if they were found sticking to the walls of Kaaba, the house of Allah, where it is normally forbidden to shed blood. One of the blasphemers identified by the Prophet was ibn-e-Khutl. He used to write derogatory poems about the Prophet and publicised them through women singers. He was killed as per the order of the Prophet.

- In another instance, there was a doubting and hypocritical Muslim man. He had a fight with a Jewish man. They took it to the Prophet Muhammad, who decided in favour of the Jew because he was right. The Muslim man was suspicious and took the matter to Hazrat Umar (one of the companions of the Prophet who later became caliph). He asked Umar to do justice because he felt that Muhammad had not been just in his decision. Umar asked him to confirm whether the decision was made by the Prophet Muhammad? He said, 'Yes.' Umar went inside his house, came back with a sword and beheaded the Muslim man. Umar said, 'This sword will decide the fate of whoever does not accept the judgement of Muhammad'. The Muslim man's family went to the Prophet to complain but the Prophet said that Umar did the right thing because the man insulted the Prophet by not accepting his decision.

- There was another man, named Utab bin Ashraf, who was very rich and used to write insulting verses about the Prophet. The Prophet one day asked all his companions, "Who will save me from the evil of this man?' There was a companion called Muhammad bin Muslima, who stepped forward and killed that man.

Hence, there are certain Quranic verses and prophetic traditions that appear in almost all religious publications, sermons, pamphlets, social media posts and so on. Not surprisingly, then, these are the same 'sources' 
that are quoted by almost every supporter of blasphemy-related violence to whom I talked. I did not explicitly ask any of them to share their religious knowledge with me; they themselves felt the need to refer to 'sources' to authenticate their beliefs and passion concerning blasphemy and its punishment. These people ranged from working-class Muslim men to government-employed, middle-class men, and from religious clerics to lawyers. Such religious discourse is thus not limited to religious scholars; it is widely distributed and is reflected in the everyday conversations of ordinary Muslims. It includes even those rural sections of society who would normally be dismissed as illiterate masses. During my research, I came across many such people who had not received any formal education, could not read or write, but who quoted Quranic verses and prophetic traditions to me. They had learnt these 'sources' and their interpretations from their local imams in Friday sermons and from other preachers on television. ${ }^{8}$

Moreover, ordinary people - even those belonging to lower socioeconomic classes and from rural backgrounds- have access to social media these days and are not only consuming but also participating in the dominant religious discourse online. This discourse provides them with meaning and inculcates passion. Hence, many religious scholars as well as common people passionately argue that anyone who commits blasphemy must be killed and does not deserve forgiveness, according to 'religious sources' and Islamic law. Their motivations are thus simultaneously embedded in cognition/reason and affect/passion. Since all refer to the 'sources' of Islamic law, it is pertinent to provide a brief overview of the traditional sources of Islamic law and their positions on the issue of blasphemy and its punishment.

\section{Blasphemy in Islamic juristic literature}

While the Quran and sunnah ('prophetic traditions') are accepted by most major sects in Pakistan as the basis of Islamic law, they mostly rely on the interpretations of major scholars from established schools of thought

8 Academic scholars have debated the authenticity and authority of the religious sources used in the current dominant religious discourse around blasphemy in Pakistan and have argued that they are not a true representation of Sharia - that is, Islamic-law (see, for example, Haq 2019). I am not concerned with the question of whether or not the dominant religious discourse is 'truly Islamic'-a question many scholars find central to studying blasphemy in Muslim societies. For me, the dominant religious discourse is significant with respect to the value and meaning it holds for people engaged in the discourse as religious scholars or their followers. 
and ijma'a ('consensus among scholars'). There are four major schools of thought within Sunni Islam (Hanafi, Shafi'i, Maliki and Hanbali) and one major school of thought in Shia Islam (Jaafari) that are practised in Pakistan. The juristic discourse between different schools of thought is mostly theological and uses legal reasoning to derive conclusions. However, there are instances of impassioned debate between Islamic jurists when it comes to the issue of protecting the honour of the Prophet and Islam. The most significant value of the juristic sources, nevertheless, lies in the authenticity and authority they grant to contemporary religious discourse.

The English word 'blasphemy' - referring to the conceptual category of sacrilege-does not correspond to a distinct respective category in Islamic jurisprudence. In Islamic literature, the words most commonly used for the concept of sacrilege include sabb ('insult'), shatam ('abuse', 'vilification'), takdhib or tajdif ('denial'), iftira ('concoction'), la'n or la'ana ('curse') and ta'n ('accuse', 'defame') (Wielderhold 1997: 40-45). Moreover, the concept of sacrilege often overlaps with those of kufr ('unbelief'), fisq ('depravity') and ridda ('apostasy') (Khan 2014: 65). Kamali (1997: 208) argued that there is a tendency in the traditional practice of fiqh ('jurisprudence') to treat blasphemy, apostasy and infidelity as 'substantially concurrent and interchangeable'. However, the concept of blasphemy is subsumed under apostasy with reference to Muslims only; a non-Muslim cannot commit the Islamic offence of apostasy. Blasphemy can, on the other hand, be committed by Muslims and non-Muslims alike (Kamali 1997: 210). Accordingly, the punishment for blasphemy has traditionally been thought of in two separate categories - that for non-Muslims committing blasphemy and for Muslims committing blasphemy.

In the case of non-Muslims, most of the Islamic juristic literature deals with those non-Muslims who live in the land of Muslims, either through invasion or through the spread of Islam such that it took hold of domestic political power (Arzt 2002: 21). Thus, the literature concerning punishment of non-Muslim blasphemers is relevant mostly in situations when the majority in society are Muslims and/or the political power belongs to Muslims. In either case, non-Muslims are given the status of dhimmis: a minority bound to pay jizya ('a form of tax', 'minority tax') to the government in return for protection of their lives (Emon 2012: 37). Under this pledge of security, the Muslim government is responsible for the lives and safety of non-Muslims living in their lands (Emon 2012). 
There are varying opinions on the punishment of a member of the dhimmi non-Muslim community who commits blasphemy (insults Islam, the Prophet or Muslim authority). ${ }^{9}$ The Hanafi school of thought-the most widely practised in Pakistan - maintains that the offence of disbelief or infidelity is the most serious crime for which non-Muslims cannot be punished if they pay jizya; thus, they cannot be killed even if they insult Islam. The punishment of a non-Muslim blasphemer is, then, discretionary (tazeer), based on what the ruler of the time deems appropriate. It can be death if the blasphemer is also a combatant, or else arrest, caning and so on. All other schools of thought (Shafi'i, Maliki, Hanbali and Jaafari) believe that dhimmis break their social contract by committing blasphemy and hence lose the protection of their lives accorded to them in return for their taxes, and therefore must be killed. The Shafi'i, Maliki and Jaafari schools have some provisions for forgiveness if the non-Muslim blasphemer converts to Islam and becomes devout.

The punishment prescribed for Muslims committing blasphemy is often harsher. They are treated as apostates because, by insulting the Prophet or the religion of Islam, they also demonstrate their unfaithfulness, disbelief and denial of Islam (O'Sullivan 2001: 82). In fact, in most cases, they are also punished for treason under the pretence of blasphemy. The punishment for apostasy, blasphemy and treason committed by a Muslim is disputed among various scholars and schools of thought. The Islamic juristic literature portrays apostasy as an unforgiveable sin that must be punished by death unless the person in question repents and returns to Islam (Saeed 2011: 32). In some cases, even repentance is not an option, and anyone suspected of apostasy is considered liable to be killed. As noted by Friedmann (2003: 123-24), 'killing the unrepentant apostate is mandatory, while an "original" unbeliever is killed only if he is a combatant'. Thus, a brief survey of the legal opinions of jurists from different schools of thought on the matter of the prescribed punishment for an apostate indicates that an adult Muslim male must be put to death unless he is not in full possession of his faculties; this is agreed on by all major schools of thought.

9 The opinions presented here are summarised from the online archive of Islamic juristic texts compiled by Engage Pakistan. Available at: engagepakistan.com/engage/digital-library-of-classicalfiqh-texts/. 
Shafi'i, Maliki and Hanbali jurists agree that an apostate should be given a chance to repent. The Hanafi school of law considers the option of repentance a desirable but not mandatory course of action. Jaafari jurists concur that an apostate should be given a chance to repent, but they limit the availability of this option only to murtadd milli ('a Muslim convert who later rejects Islam'). The exact duration allowed for the incumbent to repent is debated among the different schools, and sometimes within one school of thought as well. However, the most common view is that an apostate should be allowed three days to repent. The ruling is somewhat different regarding female apostates in some of the schools of law. According to Hanafi and Jaafari jurists, female apostates should not be killed; rather, they are to be imprisoned, or tortured by their masters if they are slaves, until they accept Islam again. According to the Hanbali, Maliki and Shafi'i schools of thought, however, women are also put to death (Jordan 2003: 62).

As we have seen, while there is debate as to whether an apostate should be imprisoned first or executed without delay, the duration of repentance allowed to an apostate and the punishment of an apostate depending on gender, there is wide consensus among Muslim jurists on the death penalty for an apostate. Most of these jurists based their verdicts on the Quran and sunnah - the two basic sources of Islamic law. While some of the scholars mentioned above have referred to Quranic verses in their writings to support their arguments or judgements, many rely mainly on the hadith literature to justify the imposition of the death penalty on apostates.

What we learn from the discussion of the traditional Islamic juristic literature is that the punishment of blasphemers and apostates has always been a matter of debate among Islamic scholars and jurists. In the traditional Islamic juristic literature, as well as in the views of the major Islamic scholars of the Subcontinent (including the founders of major subsects such as Barelwis and Deobandis) in the pre-Partition era, there have always been certain qualifications of the argument concerning the punishment of blasphemers (Mazhar 2015). Comparing this with the current positions adopted by scholars, we see that the nuances of debate concerning the frequency and intent of the offence, the possibility of repentance and different punishments prescribed for Muslims, nonMuslims, slaves, free people, men and women have largely been lost. 


\section{Competing claims to religious authority and the rise of absolutist claims}

The present consensus among religious scholars on the killing of blasphemers, as demonstrated by the dominant religious discourse, reflects a shift towards absolutist claims regarding the punishment of blasphemy and all other offences it subsumes. I argue that the current absolutist claims regarding the punishment of alleged blasphemers are an outcome of the dual nature of modernity: its desire for order and neat categorisation, on the one hand, and the anxiety caused by a growing multiplicity of opinions on the other. The modern condition is characterised by simultaneous homogenisation and heterogenisation, as described by Appadurai (1990: 295). Following Appadurai's theory, I argue that there are two distinct characteristics that define the prevalent religious discourse concerning blasphemy in contemporary Pakistan:

1. The homogenisation of the concept of the offence of blasphemy and the understanding of its punishment in absolutist terms.

2. The heterogenisation of religious authority, marking a shift from traditional structures to an unregulated multiplication of opinions and scholars.

First, we see that the various qualifications of the argument concerning the punishment of a blasphemer are removed, leading to absolutist understandings of the offence and its punishment. Representatives of most major sects and subsects in present-day Pakistan seem to have a homogeneous conception of the punishment for a blasphemer. The punishment of death for anyone who commits blasphemy against the Prophet Muhammad is arguably a unique point of consensus between all sects. Moreover, as noted earlier, various categories and concepts of offences are now subsumed under the popular imposed/appropriated Western term 'blasphemy' or the Urdu term tauheen-e-risalat. Various offences, including that of apostasy, are labelled under these terms in the popular religious discourse. Even though there is no punishment for apostasy in the PPC, the offence of apostasy-particularly with reference to Ahmadis-is understood as blasphemy and, more particularly, as an insult to the Prophet. Thus, we see modernity's emphasis on neat categorisations and the desire for order and homogenisation reflected in the contemporary absolutist religious discourse. 
Second, compared with traditional religious authority, religious authority in contemporary Pakistan is a lot more fluid and dispersed. While Islam never had a consolidated central orthodoxy like Christianity, there were established schools of thought that were accepted as legal and juristic authorities after the initial formative period. In his work on continuity and change in Islamic legal authority, Wael Hallaq (2004: 123) highlighted that a multiplicity of doctrinal narratives was a norm even during the era of consolidation of the major schools of thought in Islam. He argued that discursive and hermeneutic practices were always a part of Islamic juristic traditions (Hallaq 2004: 127). However, the discursive changes in traditional schools of thought, as Hallaq (2004: 166) argued, took place within the established structures of authority. The new and emerging scholars were first trained in established schools of thought, and their interpretations were then produced and defended, rejected or recognised within the existing structures. The structure of religious authority and the relevant discursive practices are quite different in present-day Pakistan. The new scholars do not have to be trained in any formal system of religious education. Their authority is mostly self-proclaimed, and legitimacy is drawn from their charisma and popularity rather than juristic training.

Robinson (2008: 265-68) argued that the modernist reformist movements among South Asian Muslims qualitatively changed the nature of religious authority. As noted in the previous chapter, some of the reformist groups completely broke away from the established schools of jurisprudence, while others, such as Deobandis and Barelwis, continued to follow the established schools of thought within Sunni Islam. Nevertheless, all the reformist groups, including the Deobandis and Barelwis, questioned the authority of the past and established newer ways of relating to the traditional schools of thought through a renewed focus on ijtihad ('independent reasoning') (Robinson 2008: 262). According to Robinson (2008: 268):

[T]he breaking of the continuous link with the past has enabled new forms of religious authority to emerge, an authority that could be made and remade in each generation and make use of the new resources of the times-a very modern kind of authority.

The newer modes of religious authority, therefore, did not require formal affiliation with an established institution of learning and could be claimed by anyone who could read the religious texts that became widely available in local languages due to the print revolution in the nineteenth century. 
The dispersal of religious authority was further enabled in Pakistan by government interventions in the institutes of religious learning. As Vali Nasr (2000b: 146-47) noted in his study of religious scholars and the rise of sectarian violence in Pakistan, the ulema ('religious scholars') are no longer trained in traditional intellectual tools and forms of knowledge associated with Islamic theological and juristic education. On the contrary, since the government's sponsorship of madrasabs during the Soviet war, the emphasis of religious education has been highly political. He writes:

So notable was the impact of the government initiative that Islamist and self-styled Islamic groups-whose members were predominantly lay and had received modern education — - began to establish madrasahs of their own. (Nasr 2000b: 147)

There has been not only a proliferation of self-proclaimed religious scholars with no formal religious education, but also a striking overlap of political parties and centres of religious learning. As already pointed out, most of the religious scholars dominating the discourse around blasphemy are also politicians. The number of politicians-cum-religious scholars has been expanding exponentially due to lack of formal requirements, such as recognition by traditional authority. There is a shift towards more organic, charismatic forms of religious authority. It is possible for anyone who can speak on matters of religion with a certain conviction and passion to establish himself as a legitimate scholar.

Hence, we see the dual forces of modernity - that is, simultaneous homogenisation and heterogenisation at play in determining the popular religious discourse and the construction of religious authority in Pakistan. The inherently contradictory nature of modernity has been pointed out by several theorists. For example, Bauman (2000: 106), a prominent theorist of modernity, argued that ambivalence and duality were inherent characteristics of modernity. On the one hand, the emphasis on categorisation, rationalisation and predictability was supposed to achieve order, homogeneity and domestication of chaos. On the other hand, the drive for homogeneity breeds uncertainty, differences and anxiety about those differences (Bauman 2000). The heterogenisation of religious opinions and the constant flow of information expose common peopleas well as religious scholars - to different and conflicting views, leading to the prevalence of uncertainty. The lack of one established truth when the modern nation-state emphasises the need for a metanarrative leaves people anxious and desiring certainty. The desire for certainty is then expressed 
in terms of absolutist claims, describing everything in terms of black and white, pure and impure, to reassert boundaries. The absolutist claims, however, concern the punishment of blasphemy and do not define what it is to blaspheme in any certain terms. The lack of definition as to what can be deemed blasphemous is in fact an added source of uncertainty. In this context, the competition of various groups and individuals for religious authority is what describes the current religious discourse concerning blasphemy in Pakistan. It is the competition for authority and legitimacy that constructs the affective meaning that the religious discourse holds for people. I will now discuss the politics of the three religious parties-JI, PAT and TLP — to demonstrate how they compete against each other to achieve legitimacy and authority in the face of the uncertainty arising from the multiplication of claims to religious authority.

\section{Politics of uncertainty and legitimacy}

JI was conceived in 1941 by Abul A'la Maududi, a reformist Sunni Muslim scholar, as a modern, pan-Islamist, anticolonial movement on the Indian Subcontinent. Initially opposed to the idea of Pakistan, JI has been a significant political party since the state's creation. While it has never won a significant number of seats in elections, it has periodically liaised with ruling and opposition parties to influence political decision-making, particularly in favour of Islamist policies. JI has always emphasised its text-based, urban, reformist Islam. Its headquarters in Mansoora, Lahore, has extensive libraries with a plethora of publications on the issue of blasphemy.

The other two organisations, PAT and TLP, represent Sunni Barelwisfollowers of the reformist-Sufi movement headed by Ahmed Raza Khan Barelwi in the early twentieth century. PAT was formed in 1989 by Tahir-ul-Qadri, a Pakistani Canadian Barelwi scholar. Tahir-ul-Qadri had been running the Minhaj-ul-Quran institute since 1980 and was also intensely involved in religious textual discourse. This organisation is registered as a university and has libraries, bookshops and publication houses associated with it. Tahir-ul-Qadri has written hundreds of books of religious interpretations, many of which concern the issue of blasphemy exclusively. He is also famous for his sermons aired through Minhaj-ulQuran's own TV channel, as well as other media. While Tahir-ul-Qadri 
spends most of his time in Canada, he occasionally visits Pakistan and has arranged events like Namoos-e-Risaalat Convention ('Honour of the Prophet Convention') in the past.

TLP is the most recently formed political organisation, registered in 2015. It emerged out of the religious organisation Labbaik ya Rasool Allah, formed by supporters of Mumtaz Qadri exclusively with the aim of protecting the honour of the Prophet (Basit 2020). This organisation was headed until his death in November 2020 by Allama Khadim Hussain Rizvi, a disabled man in a wheelchair who travelled across the country to address his followers. Rizvi connected with his supporters in the Punjabi vernacular popular among the working classes. TLP's discourse is disseminated largely through religious sermons given in mosques and in the street, their recordings and live screenings posted on social media, pamphlets, street protests, banners and so on.

Together, these three organisations are actively involved in producing the dominant discourse about the punishment of blasphemy in Pakistan. Despite the proliferation of religious scholars claiming religious authority and political power, their political claims greatly overlap. All three of the political parties under discussion have mandates concerning widespread social and political reforms based on Islamic ideology. JI's constitution (Article 4) defines their mission as the establishment of the Deen ['Divine Order' or the Islamic way of life] and in essence the achievement of Allah's pleasure and success in the Hereafter'. They further explain the scope of the establishment of 'Divine Order':

Establishment of Deen does not mean establishing some part of it, rather establishing it in its entirety, in individual and collective life, and whether it pertains to prayers or fasting, Haj or Zakat, or political issues of life. No part of Islam is irrelevant, but the whole Islam is necessary.

In the recent past, JI has been very active in anticorruption campaigns against the government, using the slogan 'Corruption-free Pakistan'. In March 2016, it led a 'train march' against corruption across the country-from Peshawar to Karachi (The News International 2016). Its members have also raised their voices against terrorism and the government's weak efforts to curb it. In a recent 'Resolution on the economic conditions in the country', they declared that, 'contrary to the government claims, the economy of the country was on the decline'. 
After quoting figures showing rising debt and worsening conditions for farmers, their statement (handed to me by a party member) included the following criticism of the government's antiterrorism actions:

The Shoora ['committee'] felt that the implementation on the NAP [National Action Plan] against terrorism in the wake of the Peshawar Army Public School [attack] was negligible and the government had failed to make any progress on most of the points of the NAP including the arrests of the culprits involved in the Peshawar tragedy. On the other hand, it said, the government had spent most of its time in an uncalled-for campaign against the mosques and madrassahs, which was aimed at harassing the religious circles instead of wiping out terrorism.

They further reported:

The JI Shoora renewed its commitment to stand by the masses especially against the problems of poverty, price hike[s], load shedding, lawlessness, and terrorism. It said that the JI would organize the oppressed and downtrodden masses in line with its people's agenda for the enforcement of the Islamic system with the ultimate aim to establish a truly Islamic welfare state.

Similarly, PAT has been rallying to 'revolutionise' the current system to create a truly Islamic welfare state based on 'participatory democracy'. PAT's current manifesto, called 'Green Revolution', developed in 2014 after mass protests against government corruption and electoral rigging, promises to bring free housing to the homeless, unemployment allowances to the unemployed and free education and health facilities for the population. It specifically takes aim at elimination of corruption to achieve its goals. The newly formed TLP lists similar objectives on its website. The TLP's mandate focuses on nine points: accountability, implementation of law, justice, free health, free education, security for all, freedom for Kashmir, utilising the media's role, a strong economy and friendly foreign relations. The TLP calls itself an 'Islamist political party' with an overall objective 'to make Pakistan an Islamic state, governed by Shariat-e-Mohammadi ['Muhammad's Sharia'], through a gradual legal, and political process'. Both PAT and TLP have also been known to condemn terrorism.

A review of these political parties' manifestos shows that a stand against corruption and distancing their Islamist agendas from terrorism are common features. Another common agenda item for these parties, as will 
be demonstrated in the discussion below, is to ensure that blasphemers are punished. While TLP was formed with an explicit aim of defending the honour of the Prophet, the other two parties also support the killing of blasphemers and have been active in anti-blasphemy campaigns. However, while they agree on certain agendas, they are also competing with each other for power and influence within the political sphere. How, then, do they establish their legitimacy and gain supporters when they are all rallying for the same causes? How does the rivalry play out with their shared goals and agendas?

It comes down to who can establish themselves as the rightful guardians of these causes. To do that, they need to make sharper and more aggressive claims than the others. Their politics involve asserting authority and legitimacy by taking ownership of a cause and making absolutist, aggressive claims to outdo each other. They fight over the ownership of a cause by claiming that they are the ones who care the most about it and represent it on the national stage. For example, a senior member of JI talked to me at length about how they were trying to bring all religious groups and parties together for the cause of protecting the honour of the Prophet. They organised a national conference on the issue of blasphemy in May 2016 after Mumtaz Qadri's execution and invited all other groups and parties to join them. The JI member complained:

Everyone saw that masses came to Qadri's funeral and made it obvious that they love the Prophet Muhammad, and Mumtaz Qadri due to his association with the Prophet. These masses and their leaders include people belonging to all schools of thought. We in Jamaat-e-Islami have been trying to bring [together] all religious groups and sects in the same forum on this issue. We believe in solidarity and we should all work together on this. We held a convention earlier this year where we invited all sects and groups and formed a joint action committee. However, some Barelwi groups do not want to come together with us because they want to use this issue for their own political gains. They do not come to the joint forums. Even though Mumtaz Qadri's father did not make them the custodian of the campaign, they have been pretending it is only their issue. Some other Barelwi groups come. But Allama Sarwat Qadri, Khadim Hussain Rizvi, etc., are not willing to come with us. 
PAT and TLP have also been organising similar national conventions where they represent themselves as the ones most concerned with, and the legitimate guardians of, the honour of the Prophet. JI and PAT both have significant women's wings and, in the past, their women members have also organised conferences on the honour of the Prophet. TLP does not have an active women's wing so far, but it has held rallies and conventions across the country and protests, including major sit-ins in Islamabad in March 2016 and November 2017. So, different religious political parties strive to outdo each other by competing for the ownership of issues such as blasphemy, which has gained tremendous symbolic power in the Pakistani political sphere.

Some of the older religious political parties, such as JI, relied on the strategy of using charity to amass support. They have an established charitable organisation called Al-Khidmat Foundation that provides health, education, disaster relief and other free community services. Similarly, Minhaj Welfare Foundation is the charity wing of Minhaj-ulQuran organisation. The more charismatic leaders of PAT and TLP are also engaged in giving public sermons to attract support. Tahir-ul-Qadri has gained the support of an urban educated population due to his textual approach: he delivers his sermons with stacks of books in front of him, reading out references from those books in Arabic, translating and sharing references to the 'sources' with the public on the spot. His approach is based on discursive reasoning and rationality. Allama Khadim Hussain Rizvi of TLP, on the other hand, was known for his passionate speeches in the Punjabi vernacular, appealing to rural, less-educated and lower socioeconomic sections of society. The fact that he was a disabled man who travelled across the country in a wheelchair, giving lectures on the love of the Prophet, often reciting verses in Arabic, added to his credibility and legitimacy. Moreover, he dissociated himself from worldly benefits to prove his altruism to the cause. For example, in one of his sermons, he said:

A police officer came to me and asked if I wanted money, political position, visa for abroad, etc. I told him that I am not concerned with any of these things they use to lure me. I am here only for the love of the Prophet. ${ }^{10}$

10 Available from: www.youtube.com/watch? $\mathrm{v}=\mathrm{axCwC}$-pywJk\& $\mathrm{t}=1185 \mathrm{~s}$. Note this video is now private, when accessed in October 2020 it was still a publicly available video; it is possible that it was made private after the passing of TLP chief Rizvi in November 2020, or because the Pakistani government banned TLP as a terrorist organisation in April 2021. 
He further said at another point in his sermon:

My only purpose is to bring the system of Nizaam-e-Mustafa ['Muhammad's system'] into practice. Once this mission has been accomplished, I will be happy to serve as a sweeper at the graves of the lovers of the Prophet - who have died defending the honour of the Prophet. ${ }^{11}$

It must be noted that the term nizaam-e-mustafa in the Pakistani political sphere is at least as old as Pakistan itself. Different political parties, including JI and PAT, have used it at various points to make their political claims. It has, however, more recently been associated with defending the honour of the Prophet. Since 2011, many religious parties have raised the call for nizaam-e-mustafa to counter the offence of blasphemy in Pakistan. Despite the widespread use of the term, all religious political parties claim they are the true custodians of nizaam-e-mustafa and that they are the only ones who can bring this system to Pakistan. Once again, we see the battle for the public imagining of the nation underlying this debate. Khadim Hussain Rizvi of TLP proclaimed while addressing a crowd of his followers in Karachi in January 2017:

There is only one way of achieving a prosperous state of Pakistan, and that is by defending the honour of the Prophet. Those who speak against me are in fact speaking against the honour of the Prophet. Now is the time that every Sunni should vote for us, to bring the religion of the Prophet, Nizaam-e-Mustafa, to the throne. It is the responsibility of every single Sunni in this country. ${ }^{12}$

In this statement, again, we see absolutist claims made to evoke support from the masses by suggesting that they are either with TLP or against the honour of the Prophet. These claims are further legitimised by the spiritual experiences attributed to Khadim Hussain Rizvi, by himself and his followers. For example, when he was arrested in early January 2017 for celebrating the murder of Salman Taseer in Lahore, there were stories going around on Facebook about his spiritual powers (Tanveer 2017). His followers claimed that:

11 Ibid.

12 Available from: www.youtube.com/watch? $\mathrm{v}=6 \mathrm{mP} 8 \mathrm{WlKg} 3 \mathrm{qc}$. Note this video is now private, when accessed in October 2020 it was still a publicly available video; it is possible that it was made private after the passing of TLP chief Rizvi in November 2020, or because the Pakistani government banned TLP as a terrorist organisation in April 2021. 
as Maulana Khadim Hussain Rizvi entered the prison cell, which was a really abject part of prison full of cockroaches, he gestured to the cockroaches and told them to stay away from him as he was there for the love of the Prophet. And no cockroach dared to come close to him.

Spiritual authenticity is attributed to religious and political leaders through such stories.

In addition to miracle-based charismatic authority, Rizvi also established himself as one who took a 'tough stand against the forces of evil'. He was known for being particularly aggressive and using swearwords against his enemies: the West, liberals, secularists, the government, the police and anyone who did not support his cause. His style of gaining legitimacy by asserting his authority in absolutist and violent terms set him apart from JI and PAT, whose tones are softer. Interestingly, while TLP has emerged relatively recently compared with JI and PAT, it became the fifth-most popular political party in the 2018 general elections. Thus, Rizvi's absolutist and more aggressive stance, his use of strong colloquial language, his disability and his pretentions to humility were some of the major factors that contributed to his popularity and legitimacy.

This is not to say that a particular party or religious scholar has won the competition to establish themselves as the most legitimate defender of the honour of the Prophet. The struggle is alive and will predictably remain so. New religious scholars and parties may emerge, the older ones may revive themselves with better strategies and techniques, but it is the process of the contestation itself that has led to the sharpening of the dominant religious discourse concerning blasphemy and the articulation of punishment in absolutist terms over time.

\section{Conclusion}

Over the past few decades, the dominant religious discourse around the punishment of blasphemy in Pakistan has become increasingly homogeneous despite the rising heterogeneity of its promotors. Amid the uncertainty created by the multiplicity of claimants to religious authority, the religious political parties have turned to competitive absolutist claims within this discourse to consolidate their own power and legitimacy. The homogeneity and absolutism of the discourse lend it a symbolic power within the religious-political sphere that becomes the focal point 
of competing claims to legitimacy by various players within this sphere. The symbolic power of the issue of blasphemy rests on its affective meaning, which appeals to people's imaginations and rouses their passions. The recent political events in Pakistan manifest the symbolic power of the absolutist discourse concerning blasphemy and its centrality to politics in contemporary Pakistan.

In November 2017, two Sunni Barelwi political parties, TLP and Sunni Tehreek, took to the streets to protest the alleged blasphemy committed by the law minister Zahid Hamid when he changed the wording of the declaration of faith in the parliamentary oath (Hasan 2017). ${ }^{13}$ The government retracted the change after the outcry from religious groups and explained it away as a clerical error. However, the religious parties were not satisfied and demanded the minister's resignation and an inquiry into who was responsible for the attempted change. The abovementioned Barelwi parties organised a rally, culminating in a sit-in at Faizabad interchange in the capital, Islamabad. The sit-in by the parties' religious leaders and thousands of their supporters continued for almost three weeks, interrupting the normal life of residents and holding the city hostage. ${ }^{14}$ In the final week of November, the government decided to disperse the protestors, which led to clashes with the police. Several people including police personnel died and hundreds were injured (Hasan 2017).

As a result, protests by infuriated religious groups spread across the country. The government had to eventually call in the army, which refused to use force against the protestors. However, the army arbitrated a peace agreement between the protestors and the government. ${ }^{15}$ As per the agreement, the law minister had to resign and the government had to accept a number of the protestors' demands, including the release without charge of arrested protestors. The law minister not only resigned but also had to issue a public statement reaffirming his faith and his firm belief in the finality of the Prophet Muhammad. In fact, the government, the military and protestors were all using the same language of their faith and love for the Prophet Muhammad to legitimise their respective positions (Wasim and Azeem 2017).

13 The declaration was changed from 'I solemnly believe in the finality of the Prophet Muhammad' to 'I believe in the finality of the Prophet Muhammad'.

14 Due to a road blockage, a child died in an ambulance, unable to reach hospital in time. Residents of the city had extreme problems commuting to schools, offices and so on.

15 The army's role as an 'arbiter' was later challenged by the Supreme Court of Pakistan. 
A small number of analysts and intellectuals saw these events as a compromise of democracy and surrender of power to agitating religious groups. While this is not something new in the history of Pakistan-as those in power have always tried to appease religious groups to amass support and legitimise themselves - the enormous political currency, and symbolic power, gained through the issue of blasphemy and the massive number of people who came out in support of the issue were astonishing for many. The dominant religious discourse has successfully engaged ordinary people, who are the primary agents involved in blasphemy accusations at the microlevel. Widespread uncertainty due to the multiplication of religious authority and religious leaders' sharpening discourse inculcates further moral anxieties among ordinary people. 
This text is taken from Finding the Enemy Within: Blasphemy Accusations and Subsequent Violence in Pakistan, by Sana Ashraf, published 2021 by ANU Press, The Australian National University, Canberra, Australia.

doi.org/10.22459/FEW.2021.02 